\title{
Economic Impacts of the Florida Citrus Industry in 2003-041
}

Alan Hodges, Mohammad Rahmani, and David Mulkey²

\section{Introduction}

The citrus industry remains a major part of Florida's agricultural and natural resource economy. However, recently it has been adversely affected by hurricanes and diseases such as citrus canker and citrus greening. This paper presents estimates of the total impacts of the Florida citrus industry on the state's economy based on production values for the 2003-2004 crop year. Estimates are presented separately for fresh market citrus fruit and for processed juices and other byproducts. Impacts are expressed in terms of output, value added, employment, labor income, and indirect business taxes.

\section{Methods}

The total economic impacts of the Florida citrus industry in 2003-04 were evaluated using published values for citrus fruit, processed juices, and byproducts, together with a regional input-output model for Florida. Data for citrus fruits were taken from reports by the USDA/National Agricultural Statistics Service and the Florida Department of Citrus, while data on value of processed citrus juices and byproducts were available from Florida Citrus Mutual, an industry trade association.

The IMPLAN Pro economic impact and social accounting software package, licensed to the University of Florida by the Minnesota Implan Group, Inc. (MIG), was used to develop a regional input-output model of the Florida economy with adjustments for the citrus industry. IMPLAN, which is an acronym for Impact Analysis for Planning, is an input-output modeling system that enables the estimation of the overall effects of changes in final demand for one or more industries in a defined region through the use of economic multipliers. Multipliers measure total changes in output, income, employment, or value added for a given change in direct output or employment, and estimate three components of change within the local area: direct effects represent the initial change in the industry in question, indirect effects represent changes in inter-industry transactions as supplying industries respond to changes in demands from the directly affected industries, and induced effects reflect changes in local spending that result from income changes in industry employee households. Social Accounting Matrix (SAM) multipliers in IMPLAN account for

1. This is EDIS document FE633, a publication of the Food and Resource Economics Department, Florida Cooperative Extension Service, Institute of Food and Agricultural Sciences, University of Florida, Gainesville, FL. Published April 2006. Please visit the EDIS website at http://edis.ifas.ufl.edu.

2. Alan Hodges, Associate-In; Mohammad Rahmani, Coordinator of Economic Analysis; and David Mulkey, Professor, Food and Resource Economics Department, Florida Cooperative Extension Service, Institute of Food and Agricultural Sciences, University of Florida, Gainesville, FL. 
capital investment, taxes, and transfer payments (e.g., social security, welfare, retirement pensions, and savings by households).

Regional models may be constructed with IMPLAN for a single county, groups of contiguous counties, or an entire state or region. In this case, the region of interest was defined as the state of Florida. Regional data for the model represent 2003, the most recent information available from the U.S. system of national accounts and the Regional Economic Information System maintained by the U.S.

Commerce Department. Information used in the model is specific to the state for industry output, employment, income, and trade while national averages are used to estimate transactions between industries. The model was constructed with all social accounts endogenous, including households, governments (state/local, federal), and capital investment.

Three industry sectors in IMPLAN were used to analyze the Florida citrus industry: fruit farming (\#5), frozen foods (\#60), and canned fruit and vegetable juices (\#61). These industry sectors are defined based on the primary product or service produced, under the North American Industry Classification System (NAICS). The output value of each major type of product was specified as an impact event in the appropriate industry sector: fresh market citrus fruit in the fruit farming sector, frozen citrus juices in the frozen foods sector, and chilled citrus juices in the canned juices sector. Values of processed byproducts were entered as impact events to the two processing sectors in proportion to their primary product values. Also, the export and local consumption values of citrus juice and byproducts were treated separately; only the direct impacts were considered for local consumption, since these values do not necessarily represent a change in overall regional economic activity.

Several adjustments were made to the IMPLAN model to reflect the special characteristics of the Florida citrus industry, as distinguished from the national economy for fruit farming and frozen/canned food processing, which includes a variety of other food commodities. The set of inputs purchased by these industries, known as production functions, is what drives the estimates of indirect and induced impacts. The production functions for the two processing sectors were adjusted, such that purchases from the fruit farming sector represented 38 percent of output, and other agricultural sectors were removed from the model. The production function for the fruit farming sector was adjusted based on budgeted production costs reported by Muraro, et al. (2004). Production expenditures for the major types of citrus and various production regions in Florida are shown in Table 1, including both fresh and processed Valencia and Hamlin oranges and white and red grapefruit in the Central, Southern, and Indian River regions, respectively. Weighted average expenditures in relation to production volume were assigned to appropriate IMPLAN sectors as indicated in Table 2. Industry purchases from other sectors included financial lenders, fertilizers, agricultural chemicals, greenhouse and nursery products, plastic pipes and fittings, other state and local government enterprises, and government (non-education). Many of the cultural operations were treated as labor inputs to production, and as such represent value added rather than industry purchases. Finally, the regional purchase coefficient for fruit farming was set to the maximum allowable level (0.88) to force the processing sectors to purchase all available fruit from local (in-state) sources. Industry information on value added, including employee compensation, proprietor income, other property income, and indirect business taxes, were left at default levels in the IMPLAN model.

\section{Results and Discussion}

The value of citrus fruit production was estimated separately for fresh market fruit and processed fruit, by citrus variety (Table 3 ). In the 2003-04 season, total citrus fruit production in Florida was 292 million boxes, including 242 million boxes of early, midseason, Navel and Valencia oranges; 41 million boxes of grapefruit; and 9 million boxes of specialty citrus (tangelos, tangerines, temples). Of the total citrus crop, some 32 million boxes (11 percent) were produced for the fresh market and 260 million boxes ( 89 percent) were utilized for processing. About 53 percent of the red seedless grapefruit was produced for the fresh market, while 80 percent of the white seedless grapefruit and 
96 percent of the oranges were processed for juice. Average free on board (F.O.B.) prices for fresh market fruit sold from packinghouses ranged from $\$ 13.20$ per box for Valencia oranges to $\$ 24.50$ for tangelos and tangerines. Average packing house door (P.H.D.) prices for processed fruit were $\$ 4.14$ per box for early, midseason, and Navel oranges; $\$ 5.82$ for Valencia oranges; and \$2.84 to \$3.02 for grapefruit. The total value of Florida citrus fruit in 2003-04 was $\$ 1.778$ billion, including fresh fruit shipments from packinghouses valued at $\$ 548$ million and fruit delivered to processing plants valued at $\$ 1.230$ billion. Red seedless grapefruit and tangerines accounted for 41 percent and 20 percent, respectively, of fresh market value. Valencia oranges represented 53 percent of the processed fruit market value, while Early, midseason, and Navel oranges accounted for 41 percent.

The value of Florida processed citrus juice product shipments in the 2003-04 season is shown in Table 4 . The total value of citrus juice products was $\$ 3.00$ billion, including $\$ 1.93$ billion for chilled (canned) juice, and $\$ 1.08$ billion for frozen concentrate juice. The vast majority of juice shipments, $\$ 2.85$ billion or 95 percent, were for processed orange juice. More than 97 percent of citrus juice products were exported outside of Florida to other states or foreign countries, while only 3 percent was consumed in the state. The share of juice consumed locally in Florida was estimated based on the Florida population and U.S. average per capita consumption.

In addition to orange and grapefruit juices, the citrus processing industry produces several other important byproducts, including citrus pulp and meal, molasses, and D-limonene. The essential oil D-limonene, recovered from the distilled extracts of fruit peel and seeds, is used for a variety of chemical products such as cleaners, disinfectants, flavors, and fragrances. Citrus pulp and meal, and molasses are sold as livestock feed ingredients. During the 2003-04 season, Florida citrus processors produced more than 1.1 million tons of citrus pulp and meal, 38,000 tons of molasses, and nearly 36 million pounds of D-limonene. The total value of these byproducts was about $\$ 136$ million (Table 5). Citrus pulp and meal represented about 66 percent of the total byproduct value.

Total economic impacts estimated for the Florida citrus industry in 2003-04 are summarized in Table 6. The direct output or sales revenue in 2003-04 was $\$ 3.69$ billion. The total output impact of the industry was $\$ 9.29$ billion, including $\$ 8.01$ billion from processed citrus juice and byproducts, and $\$ 1.28$ billion from fresh market citrus fruit sales. The indirect output impacts resulting from purchases of inputs from other industry sectors, including the purchase of round fruit from growers by the processing sector, were $\$ 1.93$ billion. The induced output impacts resulting from consumer spending by employee households were $\$ 3.67$ billion. The ratio between the total output impact and direct output implies an overall multiplier effect of 2.52. These multiplier effects are significant because the export-based nature of the Florida citrus industry brings new money into the state economy.

Total employment impact of the Florida citrus industry was 76,336 jobs, with 61,307 jobs from the processing sector and 15,029 jobs from fresh fruit. These employment impacts represent both full-time and part-time jobs, and are not adjusted to a full-time equivalent basis. Total value added impacts were $\$ 4.87$ billion. Value added is a broad measure of total labor and property income generated, and is equivalent to industry output less industry purchases. The value added impact of the citrus industry represented 0.9 percent of the gross state product of Florida in 2003 ( $\$ 548$ billion). Labor income impacts amounted to $\$ 2.73$ billion, which represents all wages and salary earnings by industry employees and proprietor's income to business owners. Indirect business tax impacts were $\$ 288$ million, which include most forms of local and state taxes, such as property tax, sales tax, water management district levies, intangible taxes, motor fuel and vehicle taxes, excise taxes, etc. but do not include federal income taxes.

Total economic impacts of Florida citrus are shown by major industry group in Table 7 . Naturally, the largest impacts occurred in the agriculture and manufacturing groups, where the direct impacts occurred from fruit farms and citrus processing. 
Output impacts in manufacturing and agriculture were $\$ 3.54$ billion and $\$ 1.58$ billion, respectively. Large output impacts also occurred in government enterprises ( $\$ 769$ million), construction ( $\$ 478$ million), finance and insurance ( $\$ 419$ million), health and social services ( $\$ 369$ million), retail trade ( $\$ 335$ million), wholesale trade ( $\$ 289$ million), professional-scientific and technical services $(\$ 288$ million), and real estate and rentals (\$225 million). Employment impacts in agriculture $(21,814$ jobs $)$ were greater than for manufacturing $(9,836$ jobs) due to the labor-intensive nature of agriculture, particularly for fruit harvesting in the citrus industry. Important employment impacts also occurred in retail trade $(5,945$ jobs $)$, health and social services $(4,897$ jobs), and construction (4,281 jobs). These impacts in other industries indicate the significant linkages of the citrus industry throughout the Florida economy.

The economic impacts of the Florida citrus industry presented here for the 2003-04 season are consistent with those reported in a previous study for the 1999-2000 season (Hodges, et al., 2001), in which total output impacts were estimated at $\$ 9.13$ billion, total employment impacts were 89,778 jobs, and total value added impacts were $\$ 4.18$ billion. This would suggest that the industry grew during the 1999-2003 period. In fact, however, total sales of fresh and processed citrus juice and byproducts have actually declined from $\$ 4.07$ billion to $\$ 3.55$ billion. Although the impact estimates in both studies were made using similar data sources and analytic procedures, there are important differences that account for this discrepancy. Notably, the earlier study was done using a previous version of the IMPLAN software, which used the Standard Industrial Classification (SIC) system rather than the NAICS. Also, it is possible that the structure of the Florida economy has become more integrated, leading to greater multiplier effects. If we use the current (2003) IMPLAN model to evaluate the direct output of fresh and processed citrus for the 1999-2000 period, we get a total output impact of $\$ 9.80$ billion (in 2003 dollars). This restated result would suggest that the total economic impact of the Florida citrus industry has declined by about 5 percent during this period in real terms.
These economic impact estimates are based on well-documented values for citrus products; however, there are certain limitations of the analysis that should be borne in mind when interpreting the results. First, the budget information for citrus fruit production was aggregated into a relatively small number of IMPLAN sectors, which may lead to an underestimate of the linkages to other sectors of the state's economy. Second, there was no specific information available for the citrus processing sector, other than purchases from the fruit farming sector, which would enable adjustment of the production function for this sector. To more accurately estimate the economic impacts of this large sector would require further details on processing expenditures.

\section{References}

Chemical Market Reporter. Price Data for D-Limonene. Available online at http://chemicalmarketreporter.com.

Feedstuffs, the Weekly Newspaper for Agribusiness, Minnetonka, MN. Price Data for Citrus Pulp and Meal, Minnetonka, MN. Available online at http://www.feedstuffs.com.

Florida Agricultural Statistics Service. 2005. Citrus Summary 2003-04, Florida Department of Agriculture and Consumer Services, Tallahassee, FL (February).

Florida Department of Citrus. 2005. Florida Citrus Outlook, 2005-06 Season. Working Paper 2005-3, Economic and Market Research Division, University of Florida, Gainesville, FL (December).

Florida Citrus Processors Association. Statistical Summary 2003-2004 Season. Winter Haven, Florida.

Florida Citrus Mutual. Annual Statistical Report, 2003-04 Season (F.O.B.Value of Florida Citrus Juice Products), Lakeland, FL.

Hodges, A.W, E. Phillippakos, W.D. Mulkey, T. Spreen, and R. Muraro. 2001. Economic Impact of Florida's Citrus Industry, 1999-2000. Economic Information Report EIR-01-02, Food and Resource Economics Department, University of Florida, Gainesville, FL (July). Available online at http://economicimpact.ifas.ufl.edu. 
Minnesota IMPLAN Group (MIG). 2006. 2003

IMPLAN Economic Impact and Social Accounting software and Data for Florida, Stillwater, MN.

Muraro, R.P., and J.W. Hebb. 2004. Budgeting Cost and Returns for Indian River Citrus Production, 2003-04. Electronic Data Information Source (EDIS) FE527. Food and Resource Economics Department, University of Florida, Gainesville, FL (September). Available online at http://edis.ifas.ufl.edu/FE527.

Muraro, R.P, W.G. Hartt, and W.C. Oswalt. 2004. Budgeting Cost and Returns for Central Florida. Citrus Production, 2003-04. Electronic Data Information Source (EDIS) FE526. Food and Resource Economics Department, University of Florida, Gainesville, FL (December). Available online at http://edis.ifas.ufl.edu/FE526.

Muraro, R.P, F.M. Roka, and R.E. Rouse. 2004. Budgeting Cost and Returns for Southwest Florida. Electronic Data Information Source (EDIS) FE528. Food and Resource Economics Department, University of Florida, Gainesville, FL (December). Available online at http://edis.ifas.ufl.edu/FE528.

USDA/NASS. 2005. Citrus Fruits. United States Department of Agriculture/National Agricultural Statistics Service Washington, D.C. (September). 


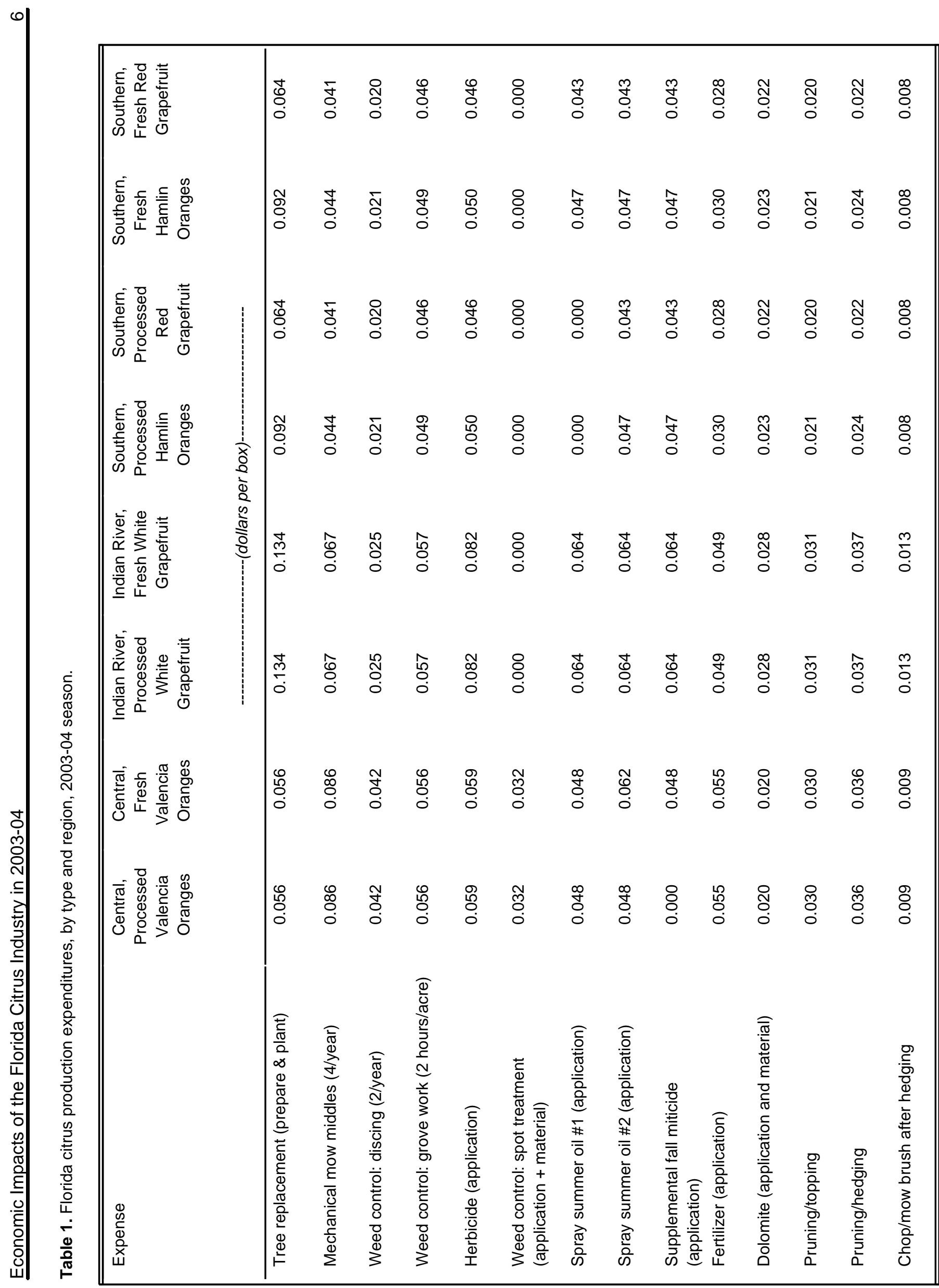




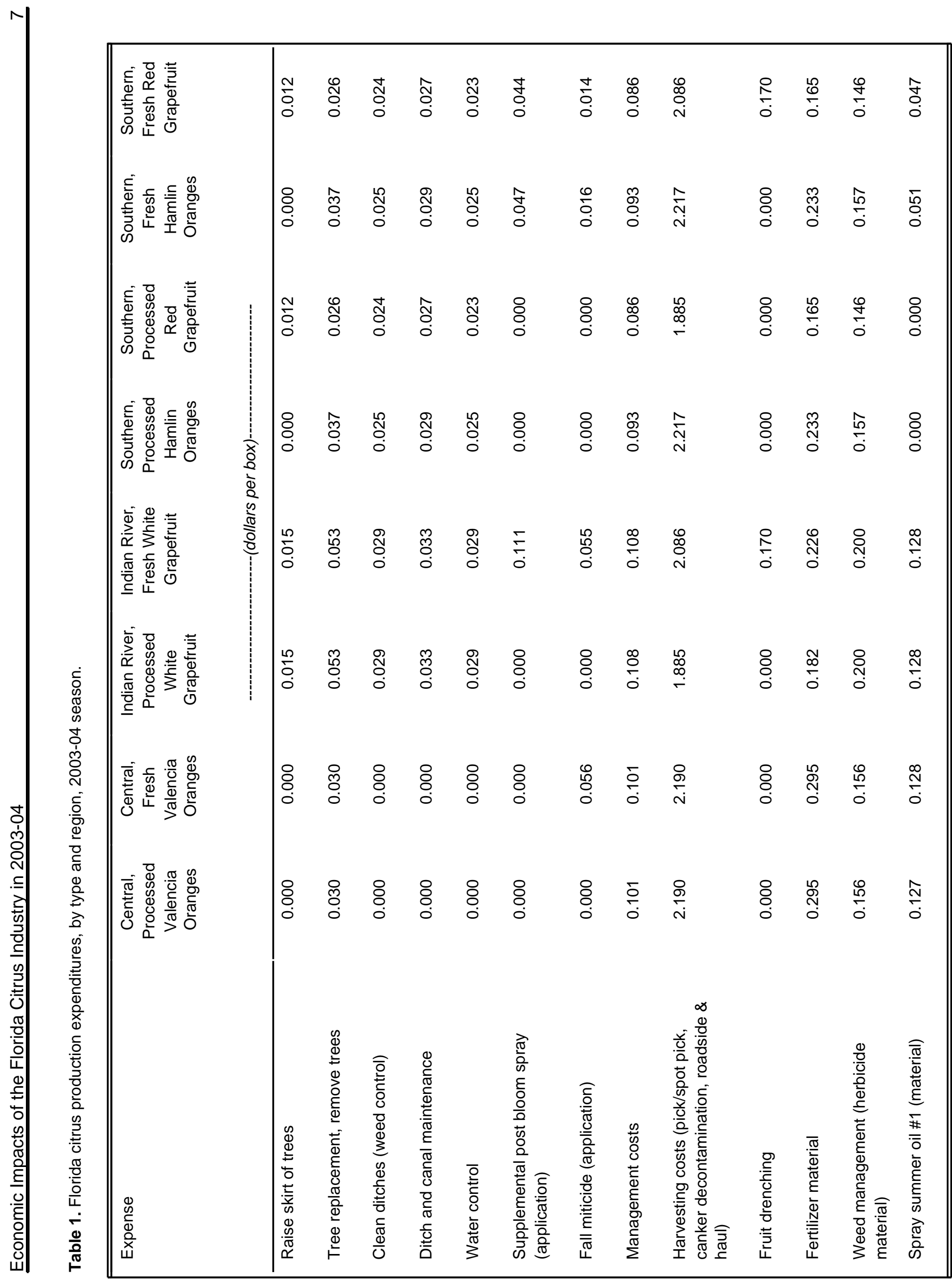




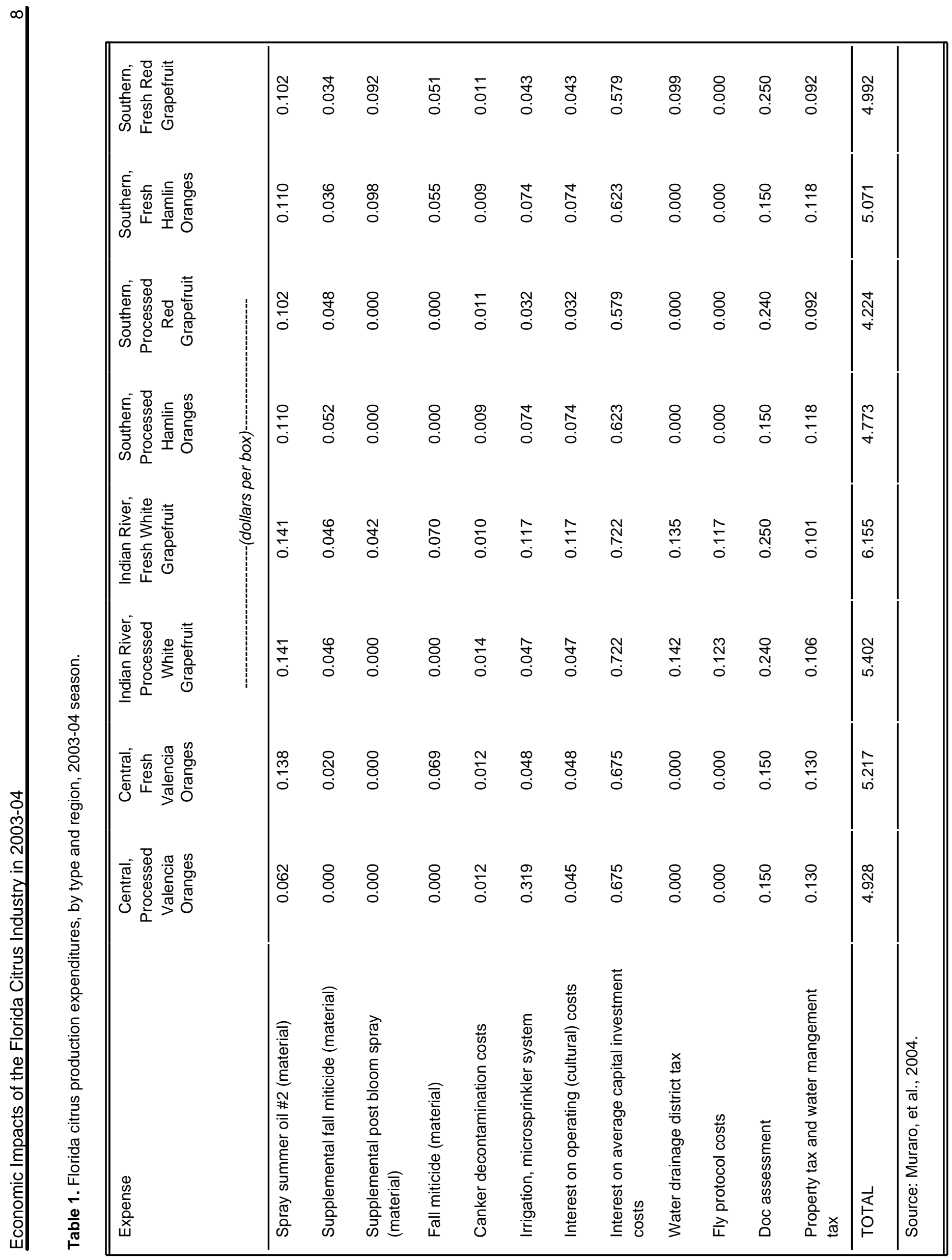


Table 2. Industry purchases for Florida citrus fruit production, by IMPLAN sector, 2003-04.

\begin{tabular}{|lrr|}
\hline \hline \multicolumn{1}{|c}{ IMPLAN Sector (number) } & Total Expenditures & Percent of Output \\
\hline Greenhouse \& nursery products (6) & (dollars) & $1.22 \%$ \\
Fertilizer mixing, manufacturing (158) & $21,589,880$ & $4.97 \%$ \\
Pesticides \& agricultural chemicals (159) & $87,820,996$ & $5.57 \%$ \\
Plastic pipes \& fittings (173) & $98,360,748$ & $4.80 \%$ \\
Financial lenders (430) & $84,838,081$ & $11.06 \%$ \\
Other state \& local government enterprises (499) & $195,331,379$ & $2.79 \%$ \\
State \& local government non-education (504) & $49,354,411$ & $1.89 \%$ \\
Total industry purchases & $33,311,668$ & $32.31 \%$ \\
\hline \hline
\end{tabular}

Table 3. Production volume, price, and value of fresh and processed Florida citrus fruit, 2003-04.

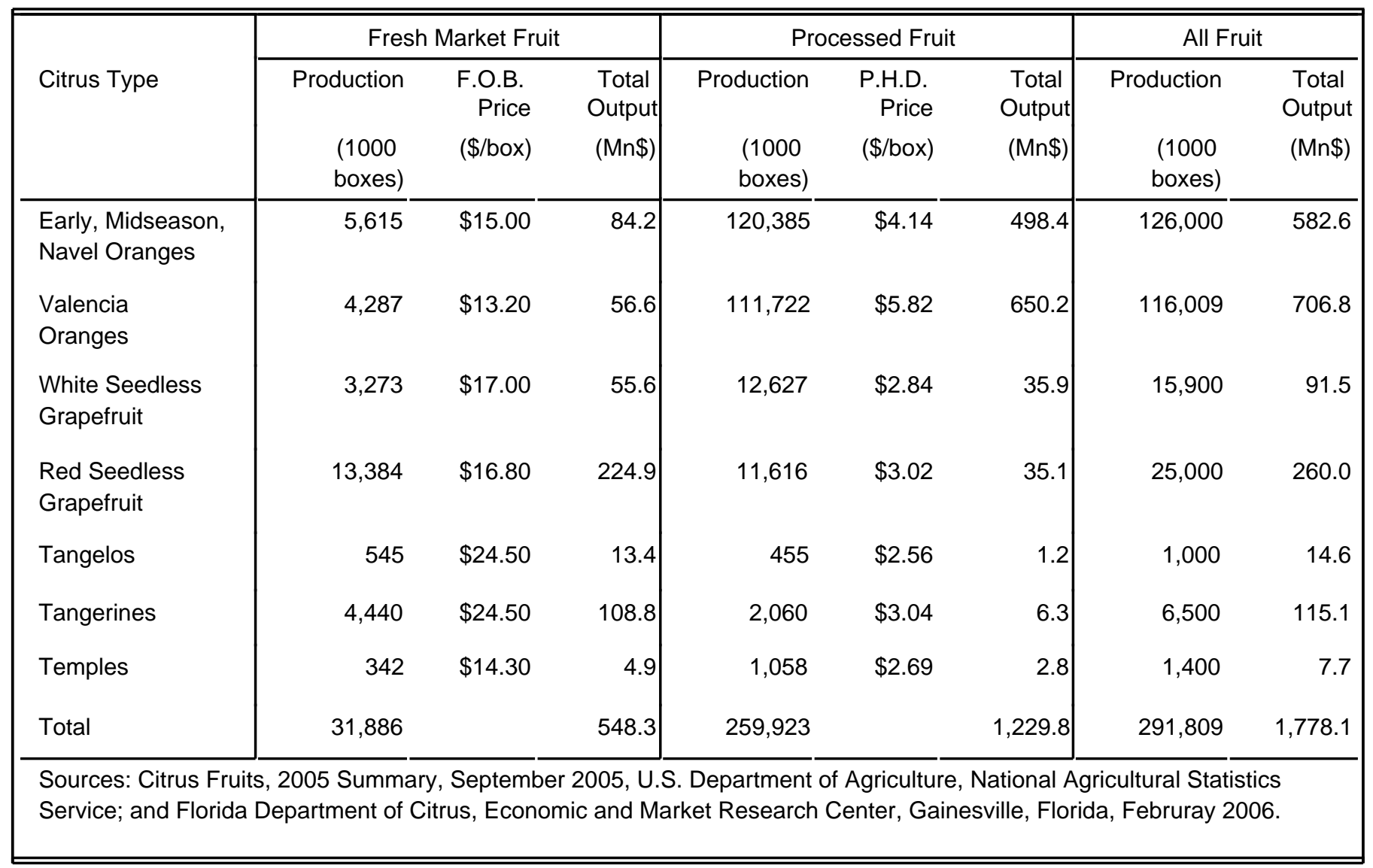


Table 4. Value of Florida frozen and canned citrus juice for local consumption and export, 2003-04 season.

\begin{tabular}{|c|c|c|c|}
\hline \multirow[t]{2}{*}{ Product } & $\begin{array}{l}\text { Export Shipments } \\
\text { (out of state) }\end{array}$ & $\begin{array}{l}\text { Local Consumption } \\
\text { (in state) }\end{array}$ & Total Value \\
\hline & \multicolumn{3}{|c|}{ 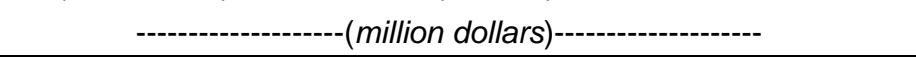 } \\
\hline Frozen orange juice & 969.3 & 31.5 & $1,000.8$ \\
\hline Chilled \& canned orange juice & $1,805.2$ & 39.7 & $1,844.9$ \\
\hline Frozen grapefruit juice & 73.9 & 1.7 & 75.6 \\
\hline Chilled \& canned grapefruit juice & 82.8 & 0.9 & 83.6 \\
\hline Total frozen citrus juice & $1,043.1$ & 33.3 & $1,076.4$ \\
\hline Total chilled \& canned citrus juice & $1,887.9$ & 40.6 & $1,928.5$ \\
\hline Total all juice products & $\overline{2,931.1}$ & 73.8 & $3,004.9$ \\
\hline
\end{tabular}

Table 5. Volume and value of processed Florida citrus byproducts, 2003-04 season.

\begin{tabular}{|lccrr|}
\hline \hline Byproduct & Production Volume & Units & $\begin{array}{r}\text { Price } \\
(\$ / \text { unit })\end{array}$ & $\begin{array}{r}\text { Total Value } \\
(\text { million } \$)\end{array}$ \\
\hline Citrus plup \& meal & $1,130,601$ & tons & $\$ 80$ & $\$ 90.5$ \\
Molasses & 38,337 & tons & $\$ 55$ & $\$ 2.1$ \\
D-Limonene & $35,782,731$ & pounds & $\$ 1.20$ & $\$ 42.9$ \\
Total & & & & $\$ 135.5$ \\
\hline Sources: Florida Citrus Processors Association, 2003-04 Statistical Summary (production volumes); & \\
Feedstuffs magainze, Chemical Market Reporter, Florida Distillers, Inc. (prices). & \\
\hline \hline
\end{tabular}

Table 6. Summary of economic impacts of the Florida citrus industry, 2003-04 season.

\begin{tabular}{|c|c|c|c|c|c|c|}
\hline $\begin{array}{l}\text { Industry } \\
\text { Sector }\end{array}$ & $\begin{array}{l}\text { Impact } \\
\text { Measure }\end{array}$ & $\begin{array}{l}\text { Output } \\
\text { (Mn\$) }\end{array}$ & $\begin{array}{r}\text { Employment } \\
\text { (jobs) }\end{array}$ & $\begin{array}{l}\text { Value } \\
\text { Added } \\
(M n \$)\end{array}$ & $\begin{array}{r}\text { Labor } \\
\text { Income } \\
(M n \$)\end{array}$ & $\begin{array}{r}\text { Indirect } \\
\text { Business } \\
\text { Taxes } \\
(M n \$)\end{array}$ \\
\hline \multirow[t]{5}{*}{$\begin{array}{l}\text { Citrus juice \& } \\
\text { byproducts }\end{array}$} & $\begin{array}{l}\text { Direct-local } \\
\text { consumption }\end{array}$ & 77.2 & 212 & 25.8 & 12.6 & 0.6 \\
\hline & Direct-exports & $3,063.2$ & 8.085 & $1,022.3$ & 495.4 & 25.4 \\
\hline & Indirect & $1,804.6$ & 19,775 & $1,106.3$ & 539.4 & 66.5 \\
\hline & Induced & $3,061.1$ & 33,235 & $1,912.0$ & $1,248.3$ & 147.7 \\
\hline & Total & $8,006.1$ & 61,307 & $4,066.3$ & $2,295.6$ & 240.2 \\
\hline \multirow{4}{*}{$\begin{array}{l}\text { Fresh Market } \\
\text { Citrus Fruit }\end{array}$} & Direct & 547.3 & 7,566 & 350.5 & 145.4 & 16.3 \\
\hline & Indirect & 127.5 & 865 & 77.1 & 41.9 & 1.9 \\
\hline & Induced & 608.0 & 6,599 & 379.3 & 248.4 & 29.1 \\
\hline & Total & $1,282.7$ & 15,029 & 806.8 & 435.8 & 47.3 \\
\hline
\end{tabular}


Table 7. Economic impacts of the Florida citrus industry, by industry group, 2003-04 season.

\begin{tabular}{|c|c|c|c|c|c|}
\hline Industry Group & $\begin{array}{l}\text { Output } \\
(M n \$)\end{array}$ & $\begin{array}{l}\text { Employment } \\
\text { (jobs) }\end{array}$ & $\begin{array}{l}\text { Value } \\
\text { Added } \\
(M n \$)\end{array}$ & $\begin{array}{l}\text { Labor } \\
\text { Income } \\
(M n \$)\end{array}$ & $\begin{array}{r}\text { Indirect } \\
\text { Business } \\
\text { Taxes } \\
(M n \$)\end{array}$ \\
\hline Agriculture, forestry, fisheries, \& hunting & $1,577.1$ & 21,814 & $1,012.0$ & 420.0 & $\overline{46.7}$ \\
\hline Mining & 9.6 & 37 & 2.2 & 0.9 & 0.2 \\
\hline Utilities & 88.3 & 163 & 60.3 & 18.5 & 8.8 \\
\hline Construction & 478.4 & 4,281 & 205.4 & 168.6 & 2.5 \\
\hline Manufacturing & $3,540.2$ & 9,836 & $1,172.2$ & 589.0 & 28.7 \\
\hline Wholesale trade & 288.7 & 2,184 & 219.6 & 123.1 & 47.4 \\
\hline Transportation \& warehousing & 159.4 & 1,712 & 88.4 & 65.0 & 3.4 \\
\hline Retail trade & 334.7 & 5,945 & 249.6 & 130.4 & 8.5 \\
\hline Information & 131.2 & 538 & 61.0 & 32.1 & 5.2 \\
\hline Finance \& insurance & 418.8 & 2,496 & 264.6 & 130.4 & 8.5 \\
\hline Real estate \& rental & 224.7 & 1,537 & 149.9 & 39.4 & 23.5 \\
\hline Professional, scientific \& technical services & 288.1 & 2,808 & 172.0 & 144.4 & 2.8 \\
\hline Management of companies & 92.5 & 578 & 55.2 & 42.5 & 0.9 \\
\hline Administrative \& waste services & 110.6 & 2,031 & 67.6 & 54.9 & 1.7 \\
\hline Educational services & 32.9 & 684 & 19.1 & 18.6 & 0.4 \\
\hline Health \& social services & 368.6 & 4,897 & 228.2 & 199.7 & 2.5 \\
\hline Arts, entertainment \& recreation & 43.5 & 741 & 27.7 & 19.0 & 2.9 \\
\hline Accomodation \& food services & 170.3 & 3,371 & 88.0 & 60.3 & 9.6 \\
\hline Other services & 162.8 & 3,066 & 85.1 & 66.0 & 6.7 \\
\hline Government and non-NAICS & 768.5 & 7,616 & 645.1 & 383.6 & 37.6 \\
\hline Total & $9,288.8$ & 76,336 & $4,873.2$ & $2,731.4$ & 287.5 \\
\hline
\end{tabular}

